\title{
Konsepsi Mahasiswa Calon Guru Sekolah Dasar Terhadap Segiempat
}

\section{Fara Virgianita Pangadongan}

Universitas Mulawarman

faravirgianita@fkip.unmul.ac.id

\section{Sejarah Artikel}

\begin{abstract}
Understanding of concepts that are relatively good and sturdy to students about a concept is sometimes not necessarily true. So it is important for an educator to be able to identify students' conceptions. This research is descriptive quantitative design. The research aims to described the preservice primary school teachers' conception about quadrilateral. The particapant of this research was 77 first year students in 2016/2017 of primary school teacher education program in Mulawarman University. To collect data, the open-ended questions was anddressed to participants and clinical interview. The results showed that conception of participants were only at the analysis level and abstraction level of Van Hiele theory. The participants were not able to establish relationships among quadrilateral due to the effect of prototypical image in choosing a family category among the given images and the critical attributes of quadrilaterals. The results of this study are expected to be a reference in the development of learning geometry by paying attention to students' conceptions.
\end{abstract}

Keywords: preservice primary school teacher, conception, quadrilateral

\section{Abstrak}

Pemahaman konsep yang relatif bagus dan kokoh pada peserta didik tentang suatu konsep terkadang belum tentu sesuai dengan konsepsi formal. Sehingga penting bagi seorang pendidik untuk dapat mengidentifikasi konsepsi peserta didiknya. Penelitian ini merupakan penelitian deskriptif kualitatif. Penelitian ini bertujuan untuk mendeskripsikan konsepsi mahasiswa calon guru Sekolah Dasar (SD) terhadap segiempat. Subjek penelitian ini adalah 77 mahasiswa program studi PGSD FKIP Universitas Mulawarman tahun ajaran 2016/2017. Instrumen penelitian yang digunakan untuk mengumpulkan data adalah pertanyaan terbuka dan wawancara. Hasil penelitian menunjukkan bahwa konsepsi subjek penelitian hanya pada level Analisis dan Level Abstraksi dari teori berpikir Van Hiele. Subjek penelitian tidak dapat menentukan hubungan antara segiempat karena efek dari pemahaman terhadap atribut kritis dan gambar prototipe yang dipilih pada sebuah kategori. Hasil penelitian ini diharapkan dapat menjadi referensi dalam pengembangan pembelajaran geometri dengan memperhatikan konsepsi mahasiswa.

Kata kunci: mahasiswa calon guru SD, konsepsi, segiempat 


\section{PENDAHULUAN}

Geometri merupakan mata
pelajaran yang penting untuk
diajarkan dalam pembelajaran
matematika. Geometri melengkapi
individu dengan keterampilan seperti
pemecahan masalah, berpikir kritis,
penalaran dan keterampilan berpikir
tingkat tinggi (NCTM, 2000).
Pembelajaran konsep geometri
membantu peserta didik
mengembangkan keterampilan penalaran dengan memahami bentuk geometris, mengeksplorasi atribut atau sifat-sifat geometri, membandingkan atribut ini dan mengembangkan bentuk klasifikasi tertentu, menghubungkan atribut bangun tersebut dan membuat kesimpulan deduktif (Erdogan, 2014)

Geometri adalah dasar dari pembelajaran matematika dan pemikiran matematika dan di sekolah dasar, geometri menempati posisi yang penting. Pada tingkat pendidikan nonformal seorang murid sudah memiliki pengetahuan awal mengenai bentuk-bentuk geometri, sehingga pada tingkat sekolah dasar (SD) siswa sudah memiliki gagasan-gagasan dasar geometris yang sederhana dan yang tidak sederhana beserta sifatsifat dari setiap bentuk geometri. Namun konsep dan rumus yang abstrak dijelaskan tanpa memperhatikan aspek-aspek seperti logika, penalaran dan pemahaman. Hal ini menjadi alasan banyak siswa berpikir bahwa geometri sangat sulit untuk dipelajari (Soedjadi, 2000).

Alkan dan Altun (dalam Biber, 2012) menyatakan bahwa setiap subjek penelitian yang belum cukup memahami konsep dasar geometri tidak akan memahami dan berhasil dalam pelajaran berikutnya. Hal ini dapat mengurangi pencapaian individu baik dalam kehidupan sekolah dan kehidupan sehari-hari. Kenyataannya sering terjadi bahwa tidak semua konsep-konsep geometri yang dipelajari oleh subjek penelitian dapat dipahami, sehingga terkadang pemahamannya terhadap konsep tidak sesuai dengan konsep ilmiah.

Materi segiempat merupakan salah satu subjek yang sering diteliti pada bidang keterampilan geometri (Van de Walle, 2012). Studi tentang segiempat dalam pengajaran geometri fokus pada identifikasi dan klasifikasi segiempat. Analisis studi ini menunjukkan bahwa siswa mengalami kesulitan dalam mengidentifikasi segiempat (Pratt \& Davison, 2003, Zaslavsky \& Shir, 2005) dan klasifikasi hierarkis (Fujita \& Jones, 2007). Klasifikasi yang hirarki tentang suatu bentuk geometri dan pemahaman dari segiempat memainkan peran kunci dalam membangun hubungan antara segiempat, pemecahan masalah, studi bukti geometrik dan mengembangkan keterampilan penalaran geometrik (Fujita \& Jones, 2007; Turnuklu et al, 2012).

Sedangkan penelitian lain yang dilakukan oleh Forsythe (2015) menunjukkan bahwa gambaran pribadi yang dimiliki peserta didik terhadap suatu bangun mempengaruhi klasifikasi segiempatnya. Sebagai contoh peserta didik mengalami kesulitan menerima bahwa belah ketupat adalah kasus khusus layang-layang. Hal lain yang diperoleh Forsythe (2018) dalam penelitiannya yang lain menunjukkan bahwa peserta didik masih menggunakan definisi parsial. Dimana menurut de Villers (1994) "the definitions that contain sulfficient information to exclude non example 
are called partitional definition". Penggunaan definisi parsial tentunya mempengaruhi klasifikasi segiempat yang dibuat oleh peserta didik. Sebagai contoh dalam penelitian Forsythe (2018) menunjukkan bahwa peserta didik mengklasifikasikan jajaran genjang dan belah ketupat sebagai bentuk yang berbeda.

Penelitian terhadap pemahaman konsep atau konsepsi tidak hanya difokuskan pada siswa sebagai peserta didik di sekolah, namun difokuskan juga pada calon guru. Guru merupakan orang yang secara formal mempengaruhi pembentukan pemahaman konsep seseorang peserta didik.

Konsepsi berasal dari kata "to conceive" yang artinya mengerti atau memahami. Kastberg (2002) menyatakan bahwa "A student's conception of a mathematical concept is his or her communicated feelings and ideas about the concept". Sfard (1991) menyatakan bahwa the whole cluster of internal representations and associations evoked by the concept the concept's counterpart in the internal, subjective "universe of human knowing", will be referred to as a "conception". Franke (2007) menyatakan bahwa konsepsi geometris yang komprehensif tentang suatu bentuk geometri sebagai konsep dari suatu objek, ditunjukkan dengan kemampuan peserta didik untuk memberi nama suatu bentuk geometri, mendefinisikan bentuk geometri tersebut, menunjukkan contoh lebih lanjut dari kategori bangun tersebut dan menyebutkan semua sifat dari bentuk geometri tersebut. Maier (2012) menyatakan bahwa untuk menyelidiki pengetahuan anak tentang bentuk geometri dan untuk menggambarkan pembentukan konsep peserta didik, dapat dilihat dari
(1) penamaan, menjelaskan dan menghubungkan bentuk geometri, (2) menggambar bentuk geometri dan (3) mengidentifikasi dan membedakan bentuk-bentuk geometri".

Penelitian tentang konsepsi calon guru matematika terhadap konsep segiempat menunjukkan walaupun subjek penelitian berpikir bahwa sebuah belahketupat adalah sebuah jajargenjang, namun mereka tidak memahami bahwa sebuah persegi adalah sebuah persegipanjang dan sebuah belahketupat (Okazaki dan Fujita, 2007). Hasil lain juga diperoleh bahwa hanya sekitar $50 \%$ dari subjek penelitian memberikan jawaban yang benar untuk pertanyaan "apakah belahketupat dan persegipanjang adalah jajargenjang atau bukan?". Zilkova (2014) menyatakan bahwa walaupun pemahaman subjek penelitian tentang konsep jajargenjang adalah pemahaman yang relatif bagus, tetapi faktanya pemahaman yang kokoh tentang suatu konsep belum tentu benar. Sebagai contoh pertanyaan tentang jajargenjang menunjukkan subjek penelitian kesulitan dalam memahaminya jika sebuah gambar berbentuk jajargenjang memiliki posisi tidak seperti pada umumnya yang mereka lihat. Selain itu subjek penelitian juga tidak dapat melihat hubungan antara belahketupat dan persegi, hal ini menurut Zilkova (2014) ada hubungannya dengan ketidakkonsistenan definisi menurut teori dari istilah di buku teks. Fujita dan Jones (2006) dan Fujita (2012) berpendapat bahwa contoh model dari suatu konsep terkadang membuat peserta didik mempunyai konsep yang tidak sesuai dengan konsep ilmiah atau miskonsepsi

Penelitian lain yang dilakukan oleh Zeybek (2017) menunjukkan bahwa 
mahasiswa calon guru mengalami kesulitan dalam menentukan hubungan antar segiempat. Pada penelitian tersebut diperoleh bahwa mahasiswa mengalami kesulitan dalam memahami definisi inklusif. Pada penelitian lanjutan yang dilakukan oleh Zeybek (2018) tentang "Understanding Inclusion Relations between Quadrilaterals" menunjukkan bahwa walaupun mahasiswa calon guru memiliki definisi formal namun gambar prototipikal memengaruhi konsepsi personal seseorang, khususnya gambaran bentuk suatu konsep. Sehingga relasi inklusif antar segiempat menjadi salah satu kesulitan bagi mahasiswa calon guru. Sebagai contoh mahasiswa calon guru mengalami kesulitan dalam melihat hubungan antara trapesium dengan segiempat lainnya.

Besarnya pengaruh gambaran bentuk suatu konsep sebagai konsepsi personal seseorang juga dapat dilihat pada hasil penelitian yang dilakukan oleh. Dalam penelitiannya yang menyatakan bahwa definisi yang diberikan oleh calon guru tentang angka-angka geometris sangat dipengaruhi oleh gambar dalam konsep figural pribadi mereka atau dalam penelitian ini disebut sebagai konsepsi personal. Sehingga Hampir sebagian besar dari mereka tidak memberikan definisi formal yang merupakan konsepsi formal. Dapat dikatakan bahwa karena ini sifat yang salah dalam konsepsi personal calon guru mengakibatkan mereka tidak dapat memberikan definisi formal.

Dari hasil penelitian di atas menunjukkan bahwa diperlukan pemahaman tentang bagaimana siswa mengkonstruk pengetahuan mereka tentang berbagai topik geometris agar guru dapat merancangkan pembelajaran yang bermakna (Battista, 1999). Ini berarti bahwa seorang pendidik dibidang matematika perlu memahami bagaimana peserta didik mengkonstruk pengetahuan geometris sebagai hasil dari pengalaman belajar mereka. Selain itu, pendidik memainkan peran kunci dalam mengkonstruk persepsi geometri bagi peserta didik. Salah satu fokus utama pendidik matematika sehubungan dengan geometri yang diajarkan di SD adalah untuk memahami bagaimana konsep geometri dipelajari oleh peserta didik. Sangat terkait dengan fokus ini adalah minat pendidik matematika dalam memahami proses pembelajaran calon guru sehubungan dengan konsep geometrik dan sifat yang seharusnya mereka ajarkan (Panaoura, 2008). Dari beberapa penelitian yang telah dilakukan sebelumnya terkait konsepsi siswa ataupun calon guru matematika menjadi pertimbangan bagi peneliti untuk meneliti lebih lanjut terkait konsepsi seseorang terhadap bangun datar segiempat. Namun pada penelitian ini difokuskan pada mahasiswa PGSD sebagai seorang calon guru SD.

Pada penelitian ini fokus yang akan dilihat oleh peneliti adalah konsepsi personal mahasiswa calon guru SD terkait dengan bagaimana pendefinisian, pengidentifikasian dan pengklasifikasian yang dilakukan oleh mereka. Dalam penelitian ini data kuantitatif dari hasil penelitian terhadap pengidentifikasian dan penggambaran terhadap bangun datar segiempat digunakan sebagai dasar untuk mengetahui bagaimana subjek penelitian mendefinisikan suatu bangun dengan melakukan wawancara lanjutan berdasarkan hasil tes. Pendefinisian yang dilakukan oleh 
subjek penelitian dikelompokkan pada atribut apa yang digunakan oleh mereka, sehingga dapat diperoleh hasil yang lebih mendalam untuk dapat membedakan definisi apa yang digunakan oleh subjek penelitian. Karena penting adanya mengetahui lebih lanjut atribut apa yang menjadi tolak ukur subjek penelitian dalam mendefinisikan suatu bangun, untuk lebih mengetahui apakah definisi inklusif atau eksklusif yang akan lebih banyak digunakan. Pendefinisian ini tentunya akan mempengaruhi hubungan antar bangun segiempat yang dibuat oleh subjek penelitian dan klasifikasinya.

Oleh karena itu, dalam upaya untuk menyelesaikan masalah terkait dengan pemahaman konsep dan pengembangan pembelajaran geometri, maka tujuan keseluruhan dari penelitian yang dilaporkan di sini adalah untuk mendeskripsikan konsepsi mahasiswa calon guru SD tentang segiempat.

\section{METODOLOGI}

Penelitian ini merupakan penelitian deskriptif kualitatif yang dimaksudkan untuk mendeskriptifkan konsepsi mahasiswa terhadap segiempat dan beberapa miskonsepsi yang dialami mahasiswa calon guru SD. Deskripsi tentang konsepsi mahasiswa didasarkan pada presentase dari hasil identifikasi, pendefinisian dan penentuan hubungan antar segiempat serta pengklasifikasiannya.

Sample pada penelitian ini adalah mahasiswa program studi Pendidikan Guru Sekolah Dasar (PGSD) pada tahun pertama pada tahun ajaran 2016/2017. Jumlah sample pada penelitian ini adalah 77 orang mahasiswa calon guru SD.

Teknik pengumpulan data dalam penelitian ini adalah tes dan wawancara. Tes yang diberikan berupa pertanyaan terbuka untuk mengidentifikasi konsepsi mahasiswa tentang segiempat, yaitu identifikasi, pendefinisian, penentuan hubungan antar segiempat serta pengklasifikasiannya. Wawancara dilaksanakan berdasarkan hasil tes yang dikerjakan subjek penelitian.

Dari hasil tes dan wawancara data dianalisis untuk mengetahui konsepsi subjek terkait pengidentifikasian segiempat dan pendefinisian yang digunakan untuk setiap bangun segiempat yang telah diidentifikasi. Selanjutnya dalam wawancara mahasiswa diminta untuk dapat menggambarkan masingmasing tiga bangun untuk setiap segiempat tersebut. Selanjutnya untuk dapat menentukan klasifikasi segiempat, dilakukan identifikasi terhadap konsepsi subjek terhadap hubungan antar segiempat dan gamabaran subjek terhadap pengkalsifikasian segiempat tersebut. Dalam penelitian ini data dianalisis dalam bentuk persentase.

\section{PEMBAHASAN}

\section{Definisi, Identifikasi dan Gambar Bentuk Segiempat}

Dalam penelitian

\section{bagian} diminta subjek untuk mengidentifikasi bangun-bangun datar yang merupakan segiempat. Kemudian subjek penelitian diminta untuk menggambarkan masing- 
masing tiga bangun untuk setiap jenis segiempat. Dari hasil identifikasi dan gambar bangun segiempat, subjek penelitian diminta untuk mendefinisikan setiap jenis bangun segiempat. Dari hasil analisis dan wawancara diperoleh bahwa subjek penelitian lebih banyak menggunakan atribut rutin (seperti sisi dan sudut) untuk dapat mengidentifikasi setiap jenis segiempat. Sedangan untuk gambaran setiap jenis bangun segiempat subjek penelitian lebih banyak menggambarkan dalam posisi standar dan tidak menggunakan simbol-simbol tertentu untuk menunjukkan atribut tertentu dari suatu bangun segiempat. Berikut tabel hasil analisis terhadap gambaran bangun segiempat subjek penelitian:

Tabel 1. Persentase Level Menggambar Subjek Penelitian.

\begin{tabular}{cccc}
\hline & $\begin{array}{c}\text { Gambar } \\
\text { tanpa Atribut }\end{array}$ & $\begin{array}{c}\text { Gambar dengan } \\
\text { Atribut }\end{array}$ & Tidak Menggambar \\
\hline \multirow{2}{*}{ Trapesium } & $50,65 \%$ & $49,35 \%$ & $5,19 \%$ \\
& $(39)$ & $(38)$ & $(4)$ \\
\hline \multirow{2}{*}{ Layang-layang } & $55,84 \%$ & $44,16 \%$ & $0,00 \%$ \\
& $(43)$ & $(34)$ & $(0)$ \\
\hline \multirow{2}{*}{ Jajargenjang } & $22,08 \%$ & $72,73 \%$ & $5,19 \%$ \\
& $(17)$ & $(50)$ & $(4)$ \\
\hline \multirow{2}{*}{ Belah ketupat } & $57,14 \%$ & $41,56 \%$ & $1,30 \%$ \\
& $(44)$ & $(32)$ & $(1)$ \\
\hline \multirow{2}{*}{ Persegi panjang } & $19,48 \%$ & $80,52 \%$ & $0,00 \%$ \\
& $(15)$ & $(62)$ & $(0)$ \\
\hline \multirow{2}{*}{ Persegi } & $50,65 \%$ & $49,35 \%$ & $0,00 \%$ \\
& $(39)$ & $(38)$ & $(0)$ \\
\hline
\end{tabular}

Dari identifikasi dan gambar yang dibuat, subjek penelitian diminta untuk menentukan definisi dari setiap jenis segiempat. Hasil analisis terhadap pengidentifikasi setiap jenis segiempat didasarkan pada sisi dan sudut (atribut rutin). Hasil analisis dijelaskan pada tabel 2 berikut ini:

Tabel 2. Persentase Pendefinisian Subjek Penelitian Berdasarkan atribut yang digunakan

\begin{tabular}{ccccc}
\hline & Sisi & Sudut & Sisi-Sudut & Tidak Menjawab \\
\hline \multirow{2}{*}{ Trapesium } & $55,84 \%$ & $3,90 \%$ & $29,87 \%$ & $10,39 \%$ \\
& $(43)$ & $(3)$ & $(23)$ & $(8)$ \\
\hline \multirow{2}{*}{ Layang-layang } & $18,18 \%$ & $2,60 \%$ & $75,32 \%$ & $3,90 \%$ \\
& $(14)$ & $(2)$ & $(58)$ & $(3)$ \\
\hline \multirow{2}{*}{ Jajargenjang } & $28,57 \%$ & $7,79 \%$ & $61,04 \%$ & $2,60 \%$ \\
& $(22)$ & $(6)$ & $(47)$ & $(2)$ \\
\hline \multirow{2}{*}{ Belah ketupat } & $12,99 \%$ & $10,39 \%$ & $72,72 \%$ & $3,90 \%$ \\
& $(10)$ & $(8)$ & $(56)$ & $(3)$ \\
\hline \multirow{2}{*}{ Persegi panjang } & $19,48 \%$ & $7,79 \%$ & $67,53 \%$ & $5,20 \%$ \\
& $(15)$ & $(6)$ & $(52)$ & $(4)$ \\
\hline Persegi & $14,29 \%$ & $2,60 \%$ & $81,81 \%$ & $1,30 \%$ \\
& $(11)$ & $(2)$ & $(63)$ & $(1)$ \\
\hline
\end{tabular}




\section{a. Trapesium}

$55,84 \%$ dari seluruh subjek penelitian mendefinisikan trapesium didasarkan pada sisinya. Mayoritas dari subjek penelitian tersebut menggunkan definisi eksklusif, yaitu trapesium adalah segiempat yang hanya memiliki dua sisi sejajar yaitu sisi atas dan bawahnya. Hanya 4,65\% dari subjek penelitian tersebut menggunakkan definisi inklusif, yaitu segiempat dengan paling sedikit dua sisi sejajar. $29,87 \%$ dari seluruh subjek menambahkan atribut sudut untuk mendefinisikan trapesium dan hanya $3,90 \%$ yang hanya menggunakan atribut sudut.

Dalam menggambarkan trapesium, selisih jumlah subjek penelitian yang menggambaran trapesium menggunakan simbol untuk menggambarkan atribut dan yang tidak menggunakan adalah kecil, yaitu $50,65 \%$ dan $49,35 \%$. Dari Hasil analisis diperoleh bahwa dalam menggambarkan subjek penelitian didasarkan pada posisi berbeda dan beberapa jenis trapesium. Berikut ini contoh gambar trapesium yang digambarkan subjek penelitian:

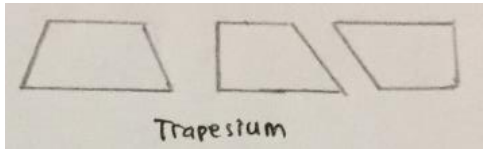

Gambar 1. Contoh gambaran Subjek Penelitian terhadap trapesium.

\section{b. Layang-layang}

$18,18 \%$ dari seluruh penelitian mendefinisikan layang didasarkan pada Subjek penelitian memperhatikan hubungan antar sisi berdekatan pada layang-layang. Dimana layang-layang diartikan sebagai segiempat yang memiliki dua pasang sisi berdekatan sama panjang. Paling banyak subjek penelitian mendefinisikan layang-layang didasarkan pada sisi dan sudut, yaitu $75,32 \%$. Sedangkan sisanya mendefinisikan layang-layang didasarkan pada sudut saja.
Sedangkan untuk mengambar bangun layang-layang, mayoritas subjek penelitian menggambarkan tanpa memberikan simbol untuk menunjukkan atribut dari bangun tersebut, yaitu sebesar $55,84 \%$ dari seluruh subjek penelitian. Dari hasil analisis terhadap gambaran dan identifikasi terhadap layang-layang diperoleh bahwa subjek penelitian mampu menggambar dan mengidentifikasi layang-layang dengan posisi berbeda. Sehingga gambaran layang-layang berbeda didasarkan pada posisi layang-layang (vertikal atau horizontal)

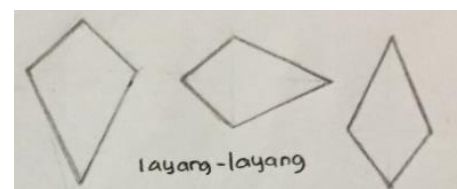

Gambar 2. Contoh gambaran Subjek Penelitian terhadap layang-layang

\section{c. Jajargenjang}

Berdasarkan tabel 2 diperoleh sebanyak $28,57 \%$ subjek penelitian menggunakan atribut kritis dari jajargenjang, yaitu panjang sisi dan kesejajaran. Subjek penelitian mendefinisikan jajargenjang sebagai segiempat yang setiap sisi 
berhadapannya sejajar dan sama panjang. $61,04 \%$ subjek penelitian menambahkan atribut tidak kritis berkaitan dengan besar sudut, yaitu sudut yang berhadapan besarnya sama dan jumlah sudut yang bedekatan adalah $180^{\circ}$. Hanya $7,79 \%$ subjek penelitian yang mendefinisikan jajargenjang hanya berdasarkan besar sudut.

Sedangkan untuk menggambarkan jajargenjang $72,73 \%$ dari seluruh subjek penelitian menggunakan atribut. Hanya 22,08\% mengambarkan tanpa atribut kritis dan ternyata masih ada 4 orang atau 5,19\% subjek penelitian tidak menggambarkan yang diminta. Dari Hasil analisis terhadap gambaran diperoleh bahwa dalam menggambarkan subjek penelitian didasarkan pada posisi berbeda. Berikut ini gambaran subjek penelitian:

\section{Gambar 3. Contoh gambaran Subjek Penelitian terhadap jajargenjang}

\section{d. Belah ketupat}

\section{$12,99 \%$}

penelitian mendefinisikan belah ketupat didasarkan pada sisinya. Subjek penelitian tersebut menggunakan sifat kesejajaran dan mendefinisikan belah ketupat sebagai sebuah segiempat dengan semua sisi sama panjang. Paling banyak subjek penelitian mendefinisikan belah ketupat didasarkan pada sisi dan sudut, yaitu $72,72 \%$. Sedangkan sisanya mendefinisikan belahketupaat didasarkan pada sudut saja.

Sedangkan untuk mengambar bangun belah ketupat dengandiperoleh $57,14 \%$ dari seluruh subjek penelitian dan hanya 1,3\% tidak menggambarkan belah ketupat. Dari hasil analisis diperoleh bahwa dalam menggambarkan tiga belah ketupat berbeda, subjek penelitian hanya didasarkan pada posisi berbeda.

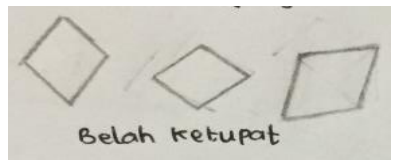

Gambar 4. Contoh gambaran Subjek Penelitian terhadap belah ketupat.

\section{e. Persegi panjang}

Lebih dari $50 \%$ subjek penelitian $(67.53 \%)$ menggunakan atribut sisi dan sudut untuk mendefinisikan persegi panjang. Sebagian besar dari mereka mendefinisikan segiempat sebagai segiempat yang setiap sisi berhadapannya sama pajang dan semua sudut sama besar. Namun subjek penelitian tidak menggunakan sifat kesejajaran dari setiap sisi berhadapannya. Dari hasil analisis hasil tes dan wawancara hanya 6 orang atau hanya $7,79 \%$ subjek penelitian yang mendefinisikan persegi panjang sebagai segiempat yang seluruh sudutnya sama besar, yaitu $90^{\circ}$

$$
80,52 \% \text { subjek penelitian }
$$
menggambarkan persegi panjang dengan memberikan simbol-simbol yang menunjukkan atribut dari 
bangun persegi panjang. Setiap subjek penelitian menggambarkan bentuk persegi panjang, namun terdapat $19,48 \%$ yang tidak mengambarkan tersebut. Dari hasil analisis diperoleh bahwa dalam menggambarkan tiga persegi panjang berbeda, subjek penelitian hanya didasarkan pada posisi berbeda dari persegi panjang.

\section{Gambar 5. Contoh gambaran Subjek Penelitian terhadap persegi panjang}

\section{f. Persegi}

$81,81 \%$ dari seluruh subjek penelitian mendefinisikan persegi sebagai segiempat yang seluruh sisi sama panjang dan sudutnya sama besar. Namun dalam mengidentifikasi sifat persegi subjek penelitian tidak memperhatikan sifat kesejajaran dari setiap sisi berhadapan. 2,60\% dari subjek penelitian berdasarkan sudutnya dan $14,29 \%$ mengidentifikasi berdasarkan sisinya.

Dari hasil analisis diperoleh bahwa dalam menggambarkan tiga persegi berbeda, subjek penelitian hanya didasarkan pada posisi berbeda dari persegi. Berikut ini contoh gamabaran subjek penelitian:

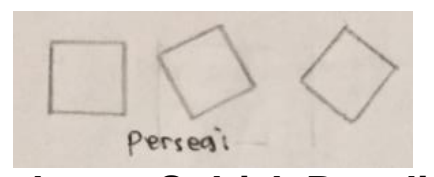

Gambar 6. Contoh gambaran Subjek Penelitian terhadap persegi

2. Hubungan antar Segiempat dan pengklasifikasian segiempat.

$46,75 \%$ dari seluruh subjek penelitian mengidentifikasi bahwa persegi panjang sebagai merupakan jajargenjang dan $28,57 \%$ subjek penelitian mengidentifikasi persegi sebagai persegi panjang. Sedangkan untuk hubungan antar jajargenjang dan belah ketupat terdapat $31,16 \%$ subjek penelitian mengidentifikasi belah ketupat sebagai jajargenjang. Sedangkan persegi diidentifikasi selalu merupakan belah ketupat oleh
$54,55 \%$ subjek penelitian dan $32,46 \%$ subjek penelitian mengidentifikasi belah ketupat sebagai layang-layang.

Sedangkan untuk bangun trapesium terdapat 4,65\% subjek penelitian menyatakan jajargenjang sebagai suatu trapesium. Hal ini disebabkan oleh definisi yang dipilih oleh mahasiswa. Mayoritas mahasiswa mendefinisikan trapesium sebagai segiempat yang memiliki tepat atau hanya sepasang sisi sejajar (Definisi Eksklusif). 


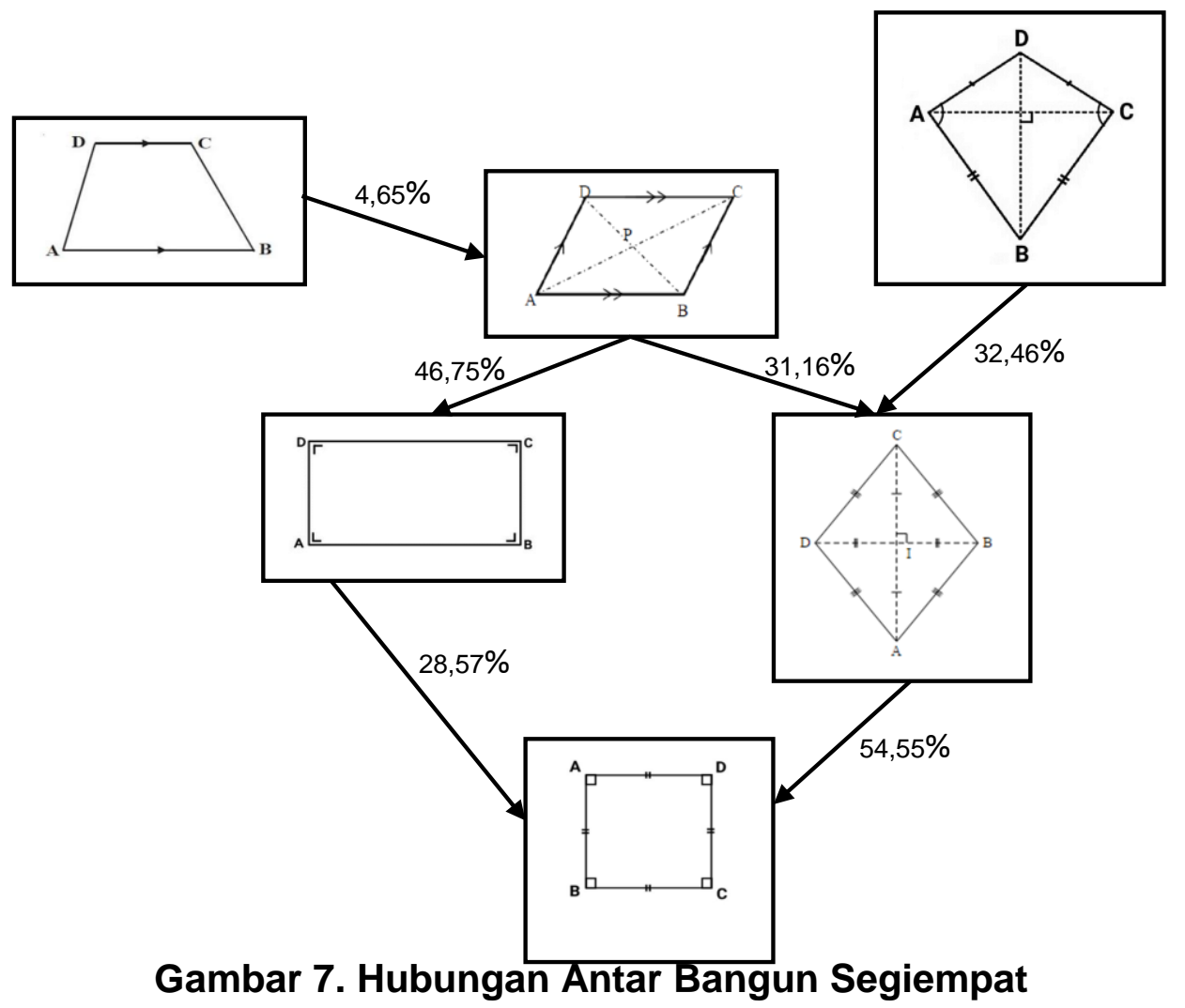

Dari hasil paparan tentang identifikasi dan definisi yang dilakukan oleh subjek penelitian diperoleh bahwa mayoritas dari subjek penelitian lebih banyak menggunakan definisi partisi dibanding definisi hierarkis. Menurut de Villiers (1994) definisi partisi adalah definisi yang mengandung informasi yang cukup untuk mengecualikan non-contoh. Sedangkan definisi hierarkis diartikan sebagai definisi yang menggambarkan semua kontain dari suatu konsep pada sifat yang dideskripsikan pada definisi dan definisi ini lebih pendek dibanding dengan definisi partisi. Sehingga dalam mendefinisikan suatu konsep hal terpenting adalah membedakan atribut kritis dan non kritis. Dari hasil analisis terhadap atribut yang digunakan oleh subjek penelitian untuk mendefinisikan suatu konsep diperoleh bahwa, untuk bangun datar layang-layang,

jajargenjang, belah ketupat dan persegi panjang kurang dari $20 \%$ dari seluruh subjek yang menggunakan atribut kritis untuk mendefinisikan bangun datar tersebut. Namun untuk pendefinisian bangun datar trapesium dan persegi, lebih dari $50 \%$ subjek penelitian menggunkan atribut kritis.

Penggunaan atribut kritis dan non kritis tentunya mempengaruhi konsepsi seseorang terhadap suatu konsep. Persepsi dari contoh prototipikal seseorang sebagai contoh yang mengandung bagian dari seluruh atribut kritis ataupun non kritis tentunya sangat mempengaruhi konsepsi seseorang. Contoh prototipikal suatu konsep dapat mencegah pemahaman yang benar dari konsep tersebut dan mengarah pada generalisasi yang salah tentang konsep tersebut (Hershkowitz 1990; Fujita dan Jones 2006). Pada penelitian ini pengaruh contoh 
prototipikal dapat dilihat pada gambaran dari suatu bangun datar. Penggunaan atribut pada gambar bangun datar dan sebagai acuan dalam mendefinisikan serta mengidentifikasi bangun datar tersebut. Lebih lanjut contoh prototipikal juga mempengaruhi klasifikasi yang dibuat oleh subjek penelitian. Sebagai contoh dalam pengklasifikasian trapesium, subjek penelitian mayoritas memahami trapesium sebagai kelas terpisah. Hal ini dikarenakan pemilihan definisi yang digunakan oleh subjek penelitian.

Hasil penelitian di atas sejalan dengan penelitian Zeybek (2018) dan Zilkova (2015) yang menyatakan bahwa lebih mudah bagi mahasiswa untuk dapat menentukan hubungan inklusi dari suatu persegi dibanding trapesium dengan bangun datar segiempat lainnya. Sedangkan menurut Forsythe (2015) klasifikasi parsial pada suatu bangun datar segiempat sebagai hasil pemahaman terhadap hubungan antar bangun datar yang merupakan contoh prototipikal seseorang juga mungkin dipengaruhi oleh konsep yang disajikan pada buku teks. Pemaparan suatu konsep pada buku teks dapat berupa atribut ataupun penggambaran. Sedangkan menurut Fujita (2012) kekeliruan penggunaan atribut pada definisi menjadi faktor terbesar kesulitan yang dialami peserta didik dalam mengkalsifikasikan segiempat. Pentingan pemahaman atribut kritis dan non kritis dinyatakan oleh Zilkova (2015) bahwa mahasiswa calon guru gagal mengidentifikasi bentuk geometris karena orientasi mereka yang berubah, dan mereka juga tidak memahami dengan baik sifat-sifat atau atribut-atribut penting dari segiempat untuk mendefinisikan bentuk tersebut.

Dari hasil paparan di atas dapat disimpulkan bahwa ada dua hal yang perlu diperhatikan dalam pengembangan dan perbaikan pembelajaran geometri. Yang pertama yaitu penggambaran konsep pada buku teks yang disajikan di buku. Kedua, pengajaran yang mengakomodir tingkat pemahaman peserta didik terhadap atribut kritis dan non kritis. Sebagaimana hasil penelitian yang menunjukkan kurangnya pemahaman siswa terhadap atribut kritis dalam pendefinisian suatu bangun datar dan pengaruh penggambaran suatu bangun datar pada buku teks.

Pentingnya pengembangan dan perbaikan pembelajaran geometri yang memperhatikan konsepsi personal peserta didik menjadi fokus dalam pembelajaran geometri. Hal ini dikarenakan persepsi dan klasifikasi bentuk geometris berkontribusi sebagai solusi dari permasalahan, baik dalam kehidupan nyata dan dalam berbagai bidang matematika (NCTM, 2000). Jadi kita dapat mengatakan klasifikasi bentuk geometris juga penting, serta mengidentifikasi mereka dalam pemikiran geometris. Disisi lain dari hasil penelitian diperoleh bahwa visualisasi terhadap suatu bangun geometri turut mempengaruhi seseorang dalam mengidentifikasi sebuah bangun datar sebagai grup dari bangun geometri lainnya.

Dari hasil penelitian ini diperoleh bahwa terdapat mahasiswa yang mengidentifikasi segiempat didasarkan pada bentuk dan posisi suatu bangun segiempat. Sehingga dapat disimpulkan subjek penelitian tersebut masih pada tahap analisis dari tahapan berpikir geometri 
menurut Van Hiele. Namun terdapat juga mahasiswa yang telah pada tahap abstraksi. Van Hiele dalam Pitajeng (2006: 42) menyatakan bahwa pada tingkat analisis ini peserta didik sudah mulai mengenal ciri-ciri yang dimiliki benda geometri yang diamati dan mengenal bangunbangun geometri tersebut berdasarkan ciri-ciri dari masingmasing bangun. Namun belum mampu mengetahui hubungan yang terkait antara suatu benda geometri dengan benda geometri yang lainnya. Sedangkan pada tahap abstraksi, peserta didik sudah mulai mampu melakukan penarikan kesimpulan, yaitu berpikir deduktif. Namun kemampuan ini belum berkembang secara penuh. Pada tahap ini peserta didik juga sudah mampu mengurutkan dan memahami hubungan antar ciriciri pada suatu bangun.

\section{SIMPULAN}

Berdasarkan penelitian tentang konsepsi mahasiswa calon guru sekolah dasar (SD) terhadap segiempat dapat disimpulkan bahwa mahasiswa mengetahui beberapa atribut dari segiempat namun masih mengalami kesulitan dalam membedakan atribut kritis dan non kritis. Sehingga mahasiswa belum dapat mengidentifikasi setiap sub grup dari suatu segiempat dan hubungan antar segiempat tersebut. Identifikasi mahasiswa terhadap segiempat lebih memperhatikan bentuk dan posisi dari bangun datar, selain itu pengidentifikasian hubungan antar segiempat dan pengklasifikasian yang dibangun mahasiswa banyak dipengaruhi oleh definisi yang dipilih dan pengambaran pada buku teks. Sehingga penting adanya untuk dapat lebih meningkatkan pemahaman mahasiswa terhadap atribut-atribut segiempat dengan memperhatikan atribut kritis dan non kritis. Peningkatan ini diharapkan dapat dilakukan melalui pembelajaran yang lebih berarti seperti penggunaan alat peraga visual dari bangun-bangun datar.

\section{DAFTAR PUSTAKA}

Battista, M.T. (1999). "The Importance of Spatial Structuring in Geometric Reasoning" . Teaching Children Mathematics, 6 (3), 170-177.

De Villiers, M. (1994). "The role and function of a hierarchical classification of quadrilaterals", Learning of Mathematics, 14(1), 11-18.

Erdogan, Emel Ozdemir. (2014). "Preservice Mathematics Teacher, Personal Figural Concept and Classification About
Quadrilaterals", Australian Journal of Teacher Education Vol 39, No. 6, pp. 120.

Forsythe, S. K. (2015). Dragging maintaining symmetry: can it generate the concept of inclusivity as well as a family of shapes? Research in Mathematics Education. 17(3), 198-219.

Forsythe, S. K. (2018). Working with the Dynamic Perpendicular Quadrilateral in a Whole Class Setting: Supporting Students in 
Developing a Hierarchical Classification of the Kites. International Journal For Mathematics Teaching And Learning. Vol 19.2 269-286

Franke, M. (2007). "Didaktik der Geometrie in der Grundschule Mathematik Primar- und Sekundarstufe". 2. Auflage. München: Spektrum Verlag.

Fujita, T., \& Jones, K. (2007). 'Learners' understanding of the definitions and hierarchical classification of quadrilaterals: towards a theoretical framing". Research in Mathematics Education , 9 (1\&2), 3-20. http://dx.doi.org/10.1080/147948 00008520167.

Hershkowitz, R. (1990). Psychological Aspects of Learning Geometry. In P Nesher \& J Kilpatrick (Eds.), Mathematics and Cognition. (pp. 70-95). Cambridge: CUP. http://dx.doi.org/10.1017/CBO97 81139013499.006.

Kastberg, S.E. (2002). "Understanding mathematical concepts: the case of the logarithmic function". Ph.D. dissertation. University of Georgia.

Kozakli Ulger, Tugce; Tapan Broutin, Menekse Seden. (2017). PreService Mathematics Teachers' Understanding of Quadrilaterals and the Internal Relationships between Quadrilaterals: The Case of Parallelograms. European Journal of Educational Research, Vol. 6. No. 3 p331345

Maier, A.S., Benz, C. (2012). "Development of Geometric Competencies- Children's Conception of Geometric Shapes in England and Germany". POEM. http://cermat.org/poem2012/main /proceedings files/MaierPOEM2012.pdf.

NCTM (National Council of Teachers of Mathematics). (2000). Principles and standards for school mathematics. Reston, VA: Author.

Panoura, G., \& Gagatsis, A. (2008). "Investigating the structures of students' geometrical performance". In A Gagatsis. Research in Mathematics Education. (pp 131-143). Nicosia: University of Cyprus.

Pitadjeng. (2006). Pembelajaran Matematika yang Menyenangkan. Departemen Pendidikan Nasional. Jakarta

Pratt, D., \& Davison, I. (2003). "Interactive whiteboards and the construction of definitions for the kite. In N. Pateman, B. J. Dougherty, \& J. Zillox (Eds.)", In Proceedings of the 27th international conference for the psychology of mathematics education (Vol. 4) Bergen, Norway, (pp. 31-38). Bergen University College.

Soedjadi. (2000). "Kiat Pendidikan Matematika di Indonesia". Direktorat Jendral Pendidikan Tinggi Departemen Pendidikan Nasional.

Turnuklu, E., Akkas, E. N., \& Gundogdu-Alayli, F. (2012). "Mathematics teachers' perceptions of quadrilaterals and students' conceptions of a mathematical definition", Journal for Research in Mathematics Education, 36(4), 317-346

Turnuklu, E., Akkas, E. N., \& Gundogdu-Alayli, F. (2012). "Mathematics teachers' perceptions of quadrilaterals and 
understanding the inclusion relations". In Eighth Congress of European Research In Mathematics Educaiton (CERME 8).

Van de Walle, J. A., Karp, K. S., \& Bay-Williams, J. M. (2012). "Elementary and Middle School Mathematics:

Teaching Developmentally (7th Edition)", Translation Ed. Durmu, S., Nobel Akademik Yayoncolok, Ankara

Zaslavsky, O., \& Shir, K. (2005). 'Students' conceptions of a mathematical definition", Journal for Research in Mathematics Education, 36(4), 317-346
Zeybek, Z. (2017). Learning To Understand Inclusion Relations Of Quadrilaterals. The Eurasia Proceedings of Educational \& Social Sciences

Zeybek, Z. (2018). Understanding Inclusion Relations between Quadrilaterals. International Journal of Research in Education and Science. Vol. 4, Issue 2. Pp 595-612

Zikova, K. (2015). "Misconception in Pre-service Primary Education Teachers about Quadrilaterals". Journal of Education, Psychology and Social Sciences. Vol. 3, Issue 1, pp 30-37 